\title{
Evaluation of surfactant activity and emulsifying of Pea protein isolate (Pisum sativum L.) obtained by the spray dryer
}

\author{
Anderson Nogueira Mendes ${ }^{3}$, Natasha Kelber ${ }^{1,2}$, Lívia Alves Filgueiras ${ }^{3}$, \\ Camila Sousa Campos da Costa ${ }^{2}$, Cristiana Pedrosa Melo Porto ${ }^{2}$, \\ Anna Paola Trindade Rocha Pierucci ${ }^{2}$, Márcio Nele ${ }^{1}$
}

\footnotetext{
${ }^{1}$ Departamento de Engenharia Química, Escola de Química, Universidade Federal do Rio de Janeiro, Rio de Janeiro, Brasil.

${ }^{2}$ Instituto de Nutrição Josué de Castro, Centro de Ciências da Saúde, Universidade Federal do Rio de Janeiro, Rio de Janeiro, Brasil.

${ }^{3}$ Departamento de Fisiologia e Biofísica, Universidade Federal do Piauí, Piauí, Teresina, Brasil. email: anderson.mendes@gmail.com
}

\begin{abstract}
This study evaluates the biosurfactant activity and emulsification ability of pea proteins isolated (Pisum sativum L.). The results showed that aqueous solutions containing the pea proteins isolated (PPI) reduce the water surface tension to $47 \mathrm{mN} / \mathrm{m}$, approximately. The use of spray dryer does not change the surfactant activity of the PPI because surface tension and CMC will not change. The PPI is thermally stable and can be used in processes that require temperatures between $4^{\circ} \mathrm{C}$ and $80^{\circ} \mathrm{C}$, as industrial processes such as baking, ice cream and other formulation. The protein isolate and pea assessed emulsions with toluene and $n$-heptane were stable. Emulsions castor and linseed oil were not stable under the conditions reported in this paper. Therefore, despite the pea protein isolate is a surfactant it cannot be used in any industrial process. Both the food industry and in the biotechnology industry should evaluate the conditions for application of protein isolates from pea.
\end{abstract}

Keywords: biosurfactant; vegetable protein; globulin; spray dryer; pea protein isolated.

\section{INTRODUCTION}

The pea (Pisum sativum) is one of the most important pulses in the world and Pea Protein Isolate (PPI) has been widely studied for its functional properties in food [1]. Its importance is due to its high protein content of $200-300 \mathrm{~g} / \mathrm{kg}$ dry matter, being an important source of protein [2]. Recent developments use the pea proteins in surfactants and cosmetics [3]. Proteins from vegetable seeds are valuable for being an alternative to animal-based sources of proteins and petroleum-derived polymers and acting as biosurfactants [1,4]. Although this is the case, investigations on non-food application of pea proteins are still scarce in the literature. Simultaneously, the increasing use of vegetable protein for human consumption has been increasingly discussed because the production is more sustainable, and may replace, at least partially, livestock ingredients, such as whey proteins [5].

The technological uses of pea proteins as biosurfactant depend largely on studies of the physicochemical properties, which are necessary for their successful incorporation into non-food systems. In contrast to the widely studied gelation properties of pea proteins [4,6], their emulsifying properties, including emulsifying ability and emulsion stability, are not as broadly investigated [7]. To date only a few studies addressing the emulsifying properties of PPI have been published [7-9].

The pea proteins are composed of $70 \%$ globulins, vicilin (7S) and legumin (11S) [5,10]. Globulins were described as potential inducers of beneficial health effects, such as anti-carcinogenic, anti-hypertensive, hypoglycemic, hypocholesterolemic [10]. Vicilin is a kind of glycoprotein that corresponds up to $35 \%$ of the total seed protein content. This protein is structured by three $50 \mathrm{kDa}$ major subunits, which are assembled to form a $150 \mathrm{kDa}$ oligomer [11]. Vicilin is the most abundant protein fraction of PPI (80\%) and its emulsifying properties are highly influenced by $\mathrm{pH}$ and heat, which may be present in industrial purification processes 
$[12,13]$.

PPI is usually produced by wet fractionation associated to isoelectric precipitation ( $\mathrm{pH} 4.8$ ), which is followed by a drying step [14]. A common drying process used in industrial applications is the spray drying, which is a well-established method for converting liquid feed materials into a dry powder when under heat [9]. Spray drying is largely used in the food and pharmaceutical industry and one of its advantages is the avoidance of microbial deterioration and reduction on the costs of storage and transport $[9,15]$. During spray drying processes heat-sensitive proteins can have structural and physical modifications due to denaturation, aggregation and formation of protein complexes, which can affect functional properties [16].

The aim of this study was to evaluate the emulsifying capacity of a pea protein isolate obtained after using the spray-dryer using different hydrophobic materials of an industrial relevance. At the same time isolated from pea protein was analyzed with respect to their surfactant activity. The results described in this article are important to give support the possible application of isolated pea protein for food industries, pharmaceutical and biotechnology.

\section{MATERIALS AND METHODS}

\subsection{Pea protein isolates (PPI) extraction and spray drying}

Green field pea seeds (Pisum sativum, L.) were purchased from a local supermarket. Peas were delipidated and milled from a powder to flour and protein was extracted from the milled flour in 10 volumes $(\mathrm{v} / \mathrm{w})$ of a $\mathrm{pH} 8.0$ solution [13]. The solution was then precipitated by adjusting the $\mathrm{pH}$ to 4.5 , getting precipitated protein (PPI-pellet) [17]. The PPI-pellet was analyzed for total protein content after appropriate dilution using albumin (BSA) as a standard [18]. The protein concentration of PPI was $22.81 \mathrm{mg}^{\mathrm{mL}} \mathrm{mL}^{-1}$. In the sequence, the PPI-pellet was solubilized by bringing the $\mathrm{pH}$ solution to 7.0 , followed by spray drying then obtaining the PPI-dried. Spray-drying was performed with a Mini Spray-dryer Büchi 190 (Büchi Laboratoriums Technik Flawil, Switzerland) with co-current operation: inlet and outlet temperature of $180{ }^{\circ} \mathrm{C}$ and $88 \pm 2{ }^{\circ} \mathrm{C}$, respectively, $0.7 \mathrm{~mm}$ nozzle and pump setting $6 \mathrm{~mL} / \mathrm{min}$. A cyclone was used to collect the powder which had a yield of $53 \pm 6 \%$ for PPI-dried. Powders were stored in closed containers within desiccators, while PPIpellets were stored in an ultra-freezer at $-80^{\circ} \mathrm{C}$ until analysis were conducted. PPI-pellet and PPI-dried was evaluated by scanning electron microscopy (SEM) using a Quanta 200 FEI microscope.

\subsection{SDS-PAGE analysis}

SDS-PAGE was performed according to Laemli (1970) methods [19]. The continuous and stacking gels were composed of $15 \%$ and $4 \%$ acrylamide respectively. The sample loading buffer contained $0.05 \mathrm{M}$ Tris- $\mathrm{HCl}$ (pH 6.8), $15 \%$ (v/v) glycerol, $0.025 \%$ bromophenol blue and $2 \%$ SDS (w/v). $\beta$-mercaptoethanol was added to the loading buffer immediately prior the utilization. Proteins bands were stained with Coomassie Brilliant Blue R.

\subsection{Surface and Interfacial Tension Measurements}

The surface tension measurements were carried out on a tensiometer Krüss K100, using the Wilhelmy plate method. The PPI-pellet and PPI-dried were dissolved in deionized water at a concentration of $3 \mathrm{~g} . \mathrm{L}^{-1}$.A shaker was used and the solution was adjusted to $\mathrm{pH} 9$ using a $\mathrm{NaOH}$ solution buffer. After, PPI-pellet and PPI-dried solutions were analyzed by the tensiometer Krüss K100, and the critical micelle concentration (CMC) was calculated [20]. Analyses of interfacial tension were performed using Krüss tensiometer DSA100 at $25^{\circ} \mathrm{C}$. This method drops the solutions of both PPI-pellet and PPI-dried, which were prepared at a concentration of 0,3 g. $\mathrm{L}^{-1}$ at $\mathrm{pH}$ 9. To measure the surface tension at different temperatures, PPI-pellet and PPI-dried were prepared at a concentration of $1 \mathrm{~g} . \mathrm{L}^{-1}$ at $\mathrm{pH}$ 9. The samples were then analyzed for 20 minutes at 4 different temperatures: $4^{\circ} \mathrm{C}, 25^{\circ} \mathrm{C}, 60^{\circ} \mathrm{C}$ and $80^{\circ} \mathrm{C}$. They were then cooled from $80^{\circ} \mathrm{C}$ to $4^{\circ} \mathrm{C}$ following the same path. The samples were stored in the refrigerator and reanalyzed the following day. The surface tension measurements at different temperatures were carried out using a tensiometer Krüss K100 by the Wilhelmy plate method.

\subsection{Emulsion stability}

The emulsions were prepared by mixing $50 \%$ water containing PPI-pellet or PPI-dried $\left(0,3\right.$ g.L $\mathrm{L}^{-1}$ ou 1 g.L $\left.\mathrm{L}^{-1}\right)$, $\mathrm{pH} 7$ or $\mathrm{pH} 9$ and $50 \%$ of hydrocarbon $(\mathrm{w} / \mathrm{w})$. The samples were sonicated by an ultrasound probe (Sonics model VCX750) for 4 minutes with amplitude of $40 \%$. Following this $20 \mathrm{ml}$ of sample was added to a flask 
for analysis of the stability of the emulsion in the Turbiscan TLAB. The emulsion stability was analyzed at room temperature by laser profiling using the Turbiscan TLAB from Formulaction ${ }^{\circledR}$. This technique allows the scanning of transmitted and scattered light of flasks containing emulsions or suspensions in various positions along the sample height. The measurement result is the light transmission and backscattering profile from the sample in function of the height of the tube $(\mathrm{mm})$, from the bottom to the top of the tube [21].

\section{RESULTS AND DISCUSSION}

The SDS-PAGE analysis showed a molecular mass range of 7S storage proteins in samples 1, 2 and 3, which is in agreement with data previously in the literature (Fig. 1) [22]. In addition to the main $50 \mathrm{kDa}$ band, preparations of purified pea vicilin contained additional bands of 38 and $33 \mathrm{kDa}$ and minor bands of $23 \mathrm{kDa}$. All of these bands result from posttranslational proteolytic processing of the intact $50 \mathrm{kDa}$ vicilin subunit [23,24].

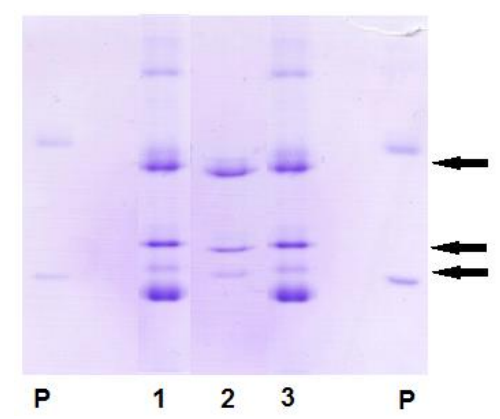

Figure 1: SDS-PAGE 15\%. Line P: Standard with albumin and carbonic anhydrase, line 1: PPI-pellet, line 2: purified pea vicilin and line 3: PPI-dried (arrows indicate the bands that correspond to the electrophoretic profile of vicilin).

Changes in $\mathrm{pH}$, temperature and interaction with salts can affect the intrinsic properties of the protein. This results in modification of the surface tension of water by loss of disulfide bonds and change in structure $[20,25]$. Thus, protein isolates could be incorporated into products which have neutral or basic $\mathrm{pH}$. In the food industry could be used in baking, diet drinks and desserts. In the biotechnology industry, the protein isolates may be used to produce compounds nutriceuticals. In other industrial processes should be observed $\mathrm{pH}$ change, because the vicilin precipitate in $\mathrm{pH}<7$, becoming insoluble [13]. Thus, all solutions were prepared at $\mathrm{pH} 9$ in order to avoid precipitation and study the characteristics of PPI-pellet and PPI-dried as its possible action surfactant.

The surface tension measurements of the PPI-pellet and PPI-dried solutions show that the samples have characteristics of surfactants. That is because there were able to lower the surface tension of water to $72 \mathrm{mN} / \mathrm{m}$ to $47 \mathrm{mN} / \mathrm{m}$ (Fig. 2). Compared with the traditional surfactants, the minimum surface tension of 47 $\mathrm{mN} / \mathrm{m}$ is quite high. However the application of the PPI in the pharmaceutical and food industries because it has variety of amino acids in composition, such as lysine, leucine, isoleucine, threonine, valine, phenylalanine, arginine, and histidine [13].

As shown in Fig. 2a, the critical micellar concentration of PPI-dried and PPI-pellet was nearly similar $\left(0,24\right.$ g.L ${ }^{-1} ; 0,23$ g.L $\left.\mathrm{L}^{-1}\right)$. These values may be attributed to concentration of vicilin, which was the same in both samples. Therefore, this result suggests the spray drier does not interfere with the properties of the protein, as shown in Fig. 2b: the variation of the surface tension of PPI-dried in aqueous solution at $\mathrm{pH} 9$ with the temperature. The results suggest that the heating and cooling did not alter the surfactant properties of the PPI-dried. 


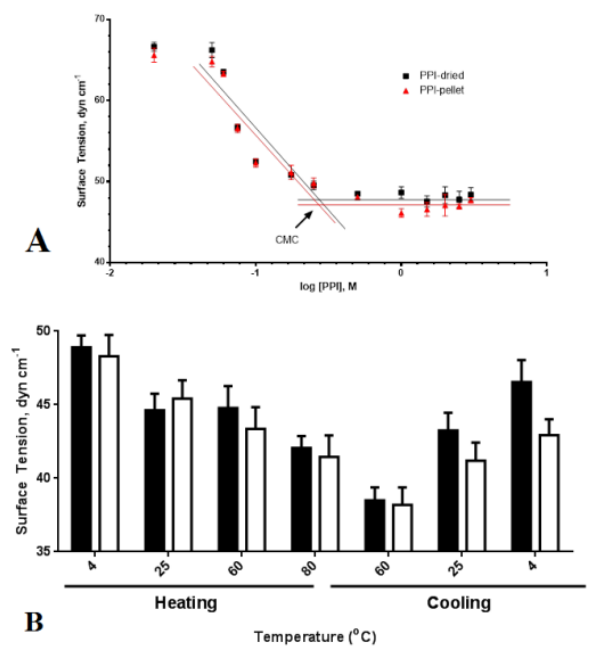

Figure 2: Surface Tension of PPI. (A) Surface Tension of samples PPI-dried and PPI-pellet in aqueous solution at pH 9 (B) Surface tension of the PPI-dried in aqueous solution at $\mathrm{pH} 9$ with the temperature. (black column corresponds to the first scan and white column corresponds to the scan after conditioning for 24 hours at $4^{\circ} \mathrm{C}$ ).

The experiments used to evaluate interfacial tension between oil and water (with or without surfactants) can contribute to the characterization of PPI-pellet and PPI-dried. As shown in Fig. 3, the interfacial tension of solutions containing PPI-dried or PPI-pellet was then compared with toluene, heptane, castor oil and linseed oil. The PPI-dried and PPI-pellet presented the same behavior towards the reduction of interfacial tension. Both the castor oil/water system and linseed oil/water, and the addition of the PPI, did not change interfacial values. The interfacial tension of water in toluene decreased from $50.2 \mathrm{mN} / \mathrm{m}$ to $32.1 \mathrm{mN} / \mathrm{m}$ in water, while heptane was reduced from $32.1 \mathrm{mN} / \mathrm{m}$ to $19.7 \mathrm{mN} / \mathrm{m}$. The PPI was able to reduce the interfacial tension of the hydrocarbons with water, but was not able to lower the interfacial tension of water with linseed oil or castor oil. This probably occurred because hydrocarbons are nonpolar molecules of single-stranded, while oils have several molecules with polar and nonpolar chains.

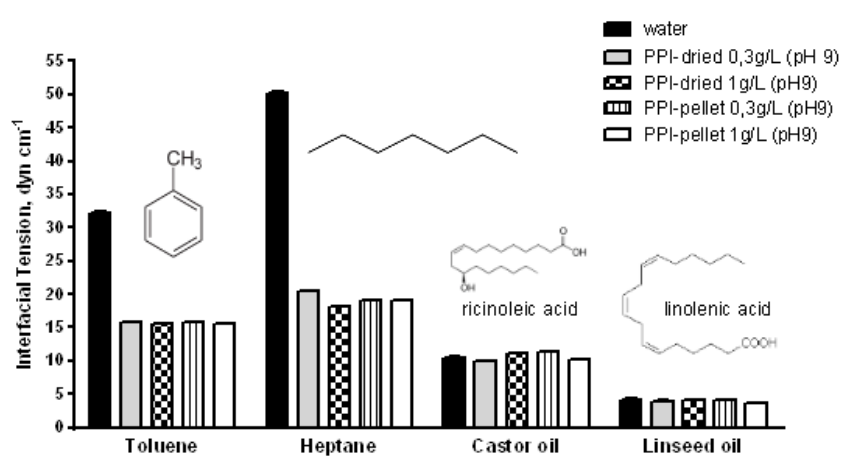

Figure 3: Interfacial tension of solutions of PPI with toluene, heptane, castor oil and linseed oil.

The molecules often have charges, and may be experiencing some incompatibility between charged molecules and PPI existing molecules in castor oil and linseed oil [26-28]. These results suggest that, PPI can interact and stabilize an emulsion containing toluene and n-heptane. However, for emulsions with linseed or castor oil, PPI pellet or dried, cannot be recommended, despite the low interfacial tension.

The emulsions of PPI have been studied to formulate oil-in-water nanoemulsions [25,29]. However, there are no studies to date that describe the capability of these compounds to reduce the surface or interfacial tension of aqueous and hydrophobic solutions.

The toluene/water emulsions were stable for at least 20 days at room temperature when added PPIdried or PPI-pellet in different concentrations. As shown in Fig. 4, the analysis using the Turbiscan show that, 
after 20 days, emulsions could be kept with $60 \%$ of emulsification. The stability of emulsions toluene and nheptane were stable for 20 days with a percentage higher than $60 \%$ of emulsification (Fig. $4 \mathrm{a}$ and $4 \mathrm{~b}$ ). The emulsions of castor oil and linseed oil in aqueous solution showed no stability, and phase separation occurred within the first 24 hours. Thus, it was not possible to evaluate the stability of emulsions with castor oil and linseed oil in such formulations.
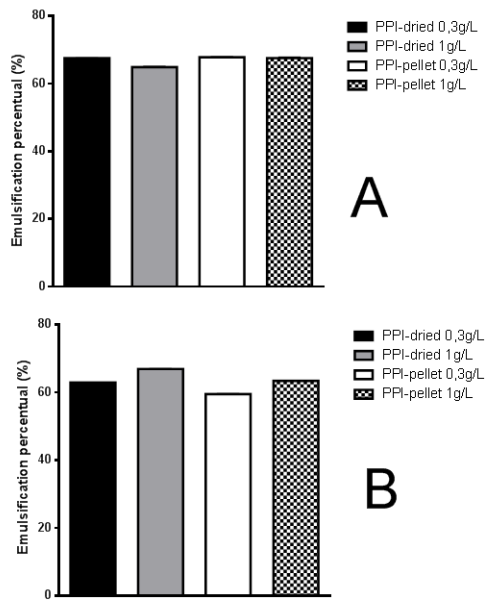

Figure 4: Percentage of emulsification. (A) Emulsion of toluene in aqueous solution containing PPI in different concentrations and $\mathrm{pH} 9$ (B) Emulsion of n-heptane in an aqueous solution containing PPI in different concentrations and $\mathrm{pH} 9$.

The technique IE24 is used for emulsification evaluation [30]. This technique is a visual method and did not accurately assess the stability of emulsions. The analysis with the Turbiscan is more detailed than the technique IE24, because it uses the backscatter of light incident on the sample. The analysis of backscatter or "backscattering" (BS(t)) allows to verify more reliably the percentage of emulsification and analyze the behavior of emulsions to determine coagulation, flocculation, coalescence and establish the size of the micelles or vesicles particles formed in the sample [20].

The variation of the backscattering Turbiscan is an important tool for detailed checking of emulsion stability. It can evaluate phase separation time based on turbidity of each sample. In Figure 5, it can be observed that the emulsions containing toluene and n-heptane remained constant during the twenty days, but varied according to the degree of turbidity $(\mathrm{BS}(\mathrm{t}))$ when compared.

The PPI-toluene emulsions varied in turbidity when increasing the concentration to $1 \mathrm{~g} . \mathrm{L}^{-1}$ of PPI. As shown in Fig. 5a, this variation may be associated with the increased size of vesicles or micelles of toluene in water. Fig. 5b shows the behavior of the emulsion PPI-toluene was different from the emulsion PPI-nheptane. The emulsions PPI-n-heptane apparently did not change, which suggests that the PPI concentration does not interfere with the turbidity of the system. Toluene is an aromatic molecule while the n-heptane is a single chain molecule. This may influence the mobilization and structure of the vesicles and micelles to form an emulsion in generating variation in turbidity. 


\section{Emulsion toluene/water}

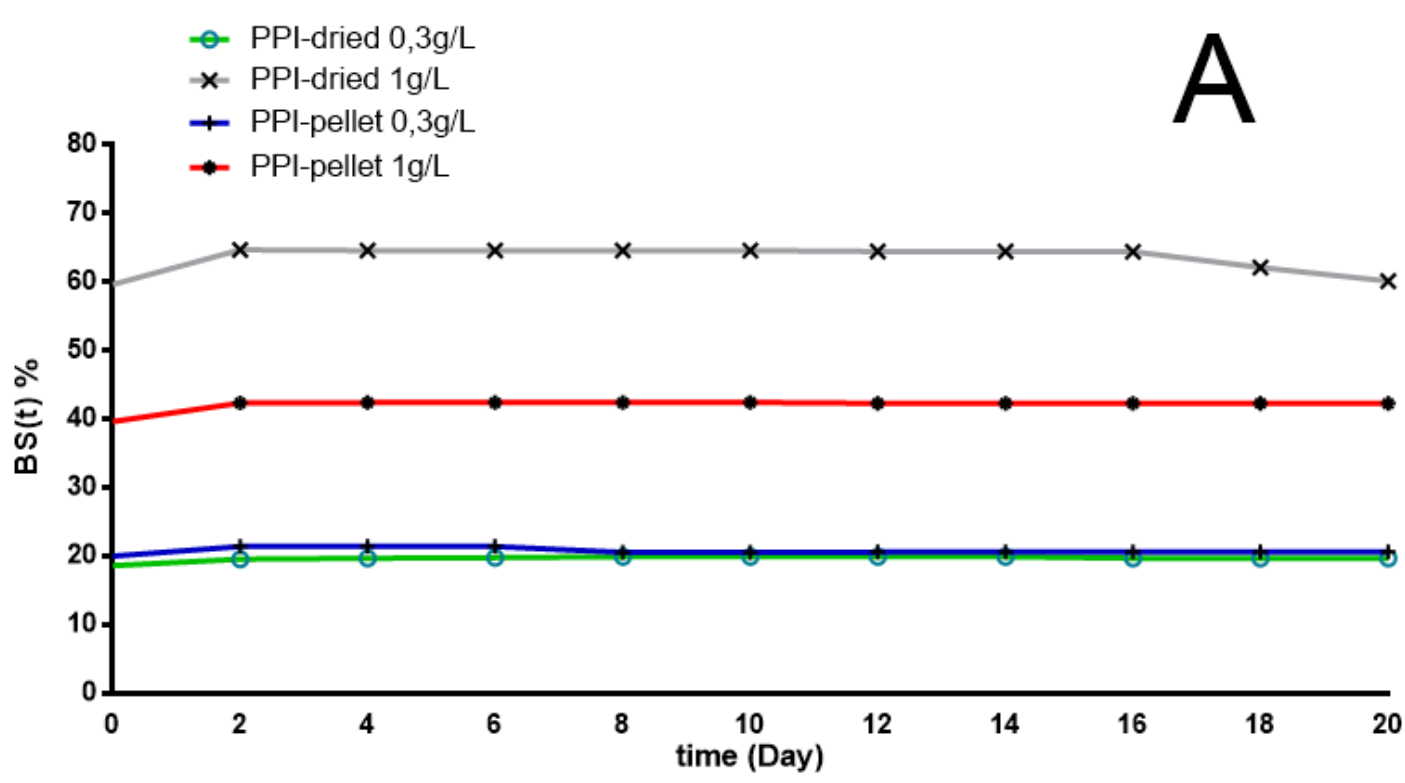

\section{Emulsion $\mathrm{n}$-heptane/water}

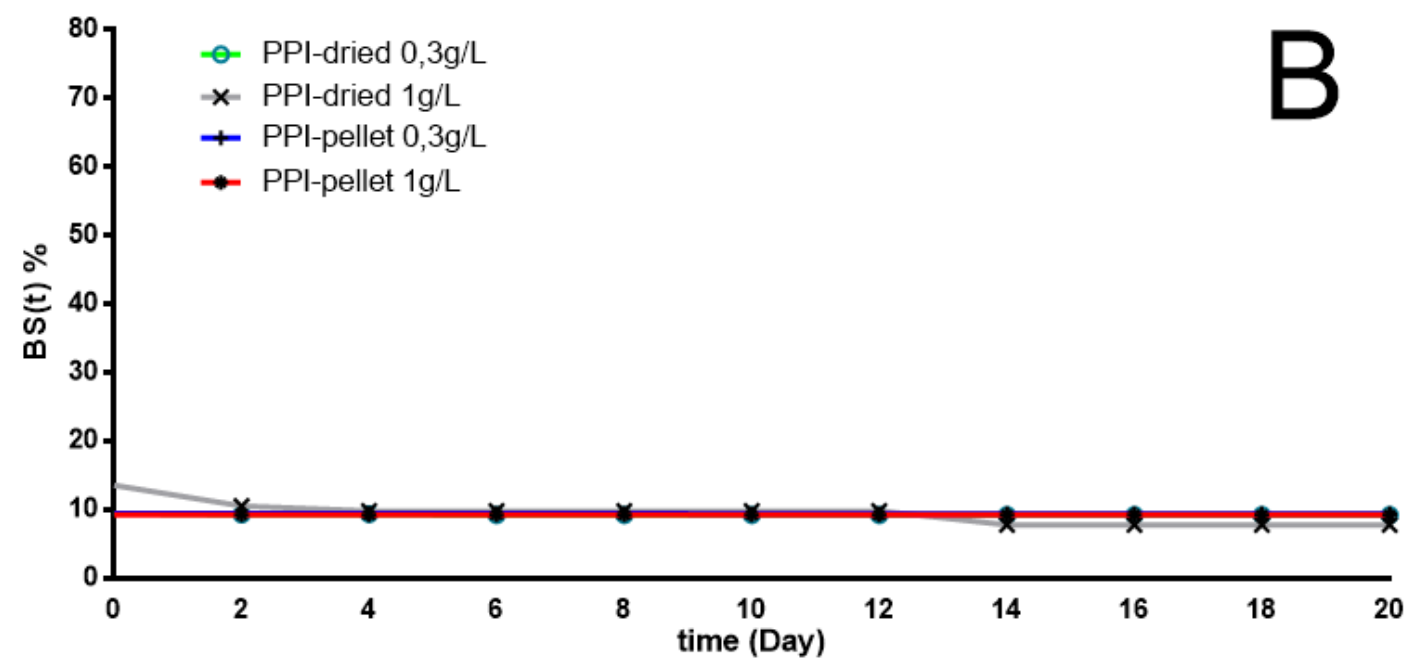

Figure 5: Backscattering (BS(t)) of emulsions PPI/hydrocarbons. (A) Emulsion of toluene in aqueous solution containing PPI in different concentrations and $\mathrm{pH} 9$ (B) Emulsion of n-heptane in an aqueous solution containing PPI in different concentrations and $\mathrm{pH} 9$.

Physico-chemical properties of the proteins are changed according to the type of solvent and parameters such as $\mathrm{pH}$, ionic strength, temperature [5]. Solvents may induce destabilization of native structure of the protein and irreversible molecular rearrangements. These changes may allow gelation of globular proteins and change the emulsifying properties. The emulsions of castor oil were presented gelified after 20 days when observed with the naked eye (Supplementary Material).

The analysis with Turbiscan shows that the backscattering and turbidity of the samples are associated with the size of the micelles and vesicles formed in the PPI emulsions (Fig. 6). All emulsions have in their formulation particles with average size less than $150 \mathrm{~nm}$. The small size changes in the emulsions of PPItoluene were due to the hydrodynamic system mobility. The emulsions PPI-toluene and PPI-n-heptane have micelles or vesicles with a size between $50 \mathrm{~nm}$ to $150 \mathrm{~nm}$. The type of hydrophobic solution (toluene and $\mathrm{n}-$ heptane), and concentration and type of PPI produced influenced this variability. These results may be useful 
for formulations containing PPI requiring nanometric size stable particles.

\section{Emulsion toluene/water}

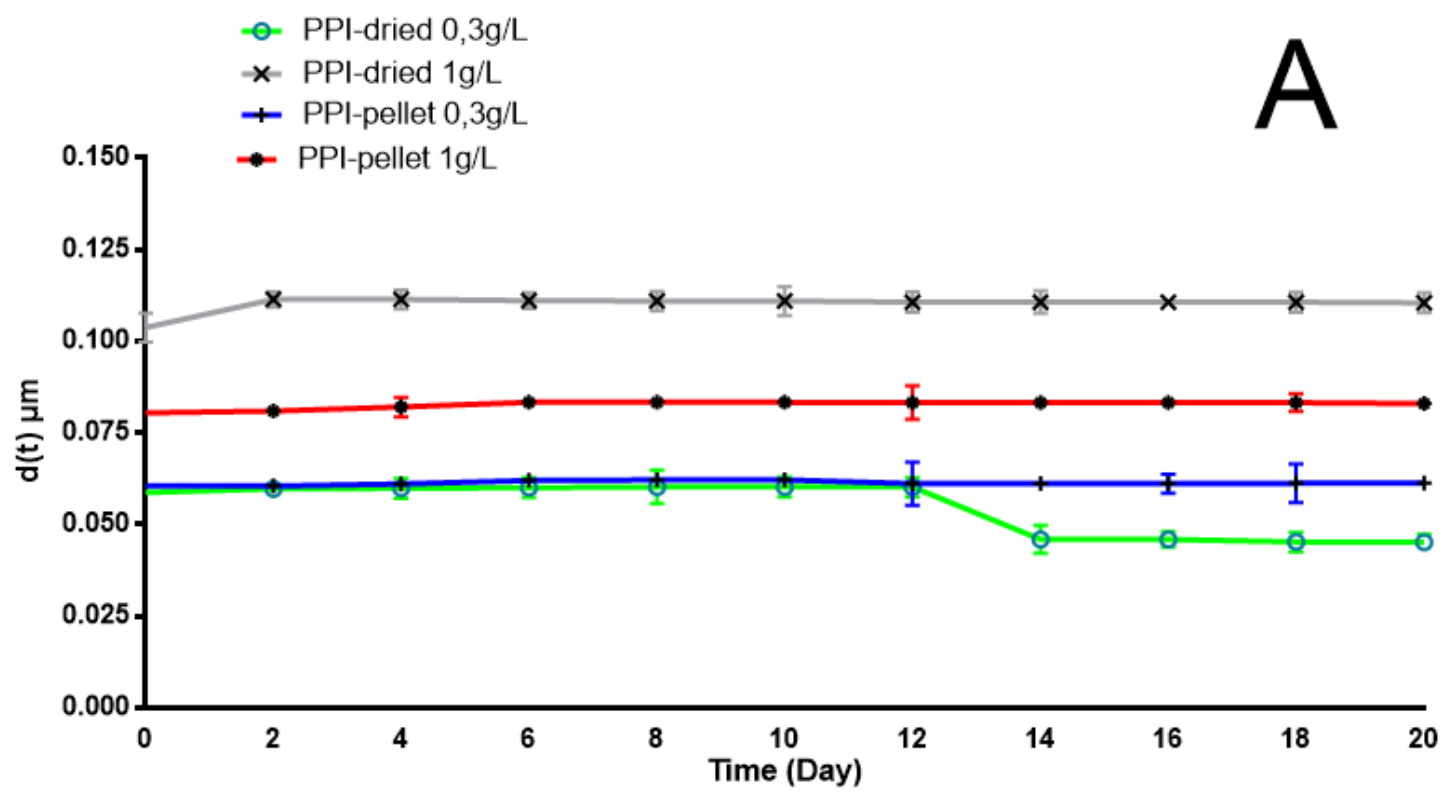

Emulsion n-heptane/water

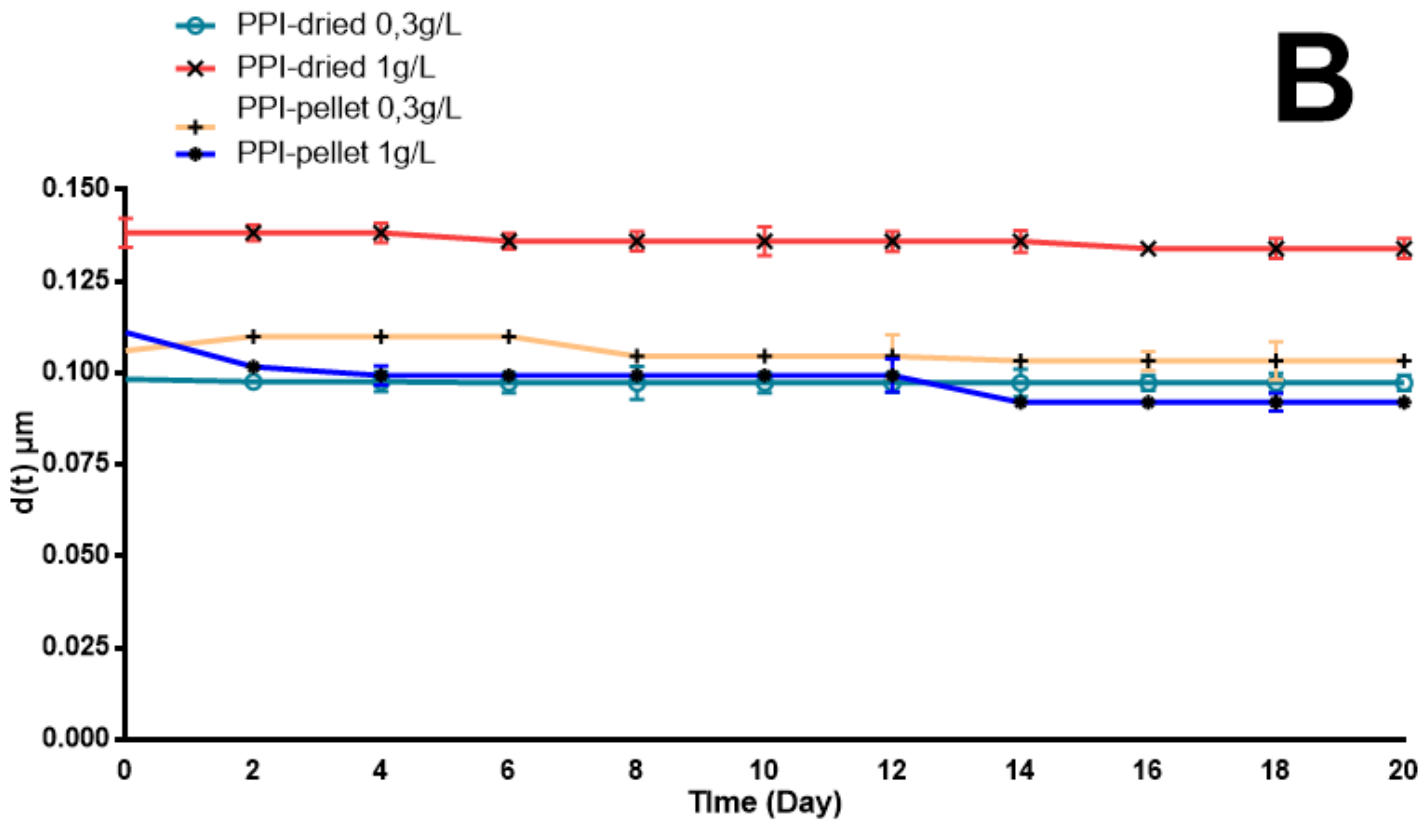

Figure 6: Variation of particle diameter $(\mathrm{d}(\mathrm{t})$ ) of emulsion PPI-hidrocarbons. (A) Emulsion of toluene in aqueous solution containing PPI in different concentrations and $\mathrm{pH} 9$ (B) Emulsion of n-heptane in an aqueous solution containing PPI in different concentrations and $\mathrm{pH} 9$.

\section{CONCLUSION}

Little information is available in the literature on the physico-chemical characterization of legume extracts, especially pea seed fractions, for emulsion processes. The pea protein isolate can be considered a biosurfac- 
tant, because it reduces the surface tension of water. The result with PPI in solution suggests that PPI can be used as surfactant in processes that require cooling or heating. This study demonstrated that physical form (dried or pellet) had no influence in the surfactant property of PPI. It is then considered that the drying process by spray drying does not interfere with the PPI properties as a surfactant. Thus, the pea protein isolate can be incorporated into industrial products (as a biosurfactant) as food industry and biotechnology since the $\mathrm{pH}$ is neutral or basic and emulsion type to be used.

\section{ACKNOWLEDGMENT}

The autors wish to thank the Conselho Nacional de Desenvolvimento Científico e Tecnológico (CNPq), Coordenação de Aperfeiçoamento de Pessoal do Ensino Superior (CAPES), for their support.

\section{BIBLIOGRAPHY}

[1] CLEMENTE, A., ARQUES, M.C, DALMAIS, M., et al., "Eliminating Anti-Nutritional Plant Food Proteins: The Case of Seed Protease Inhibitors in Pea", PLoS One, v.10, n.8, e0134634, 2015.

[2] MERTENS, C., DEHON, L., BOURGEOIS, A, et al., "Agronomical factors influencing the legumin/vicilin ratio in pea (Pisum sativum L.) seeds”, J. Sci. Food Agric., v.92, n.8, pp.1591-1596, 2012.

[3] RONDEL, C, PORTET, B, ALRIC, I, et al., "Green Production of Anionic Surfactant Obtained from Pea Protein”, J. Surfactants Deterg., v.14, n.4, pp.535-544, 2011.

[4] O'KANE, F.E., VEREIJKEN, J.M., GRUPPEN H., et al., "Gelation Behavior of Protein Isolates Extracted from 5 Cultivars of Pisum sativum L”, J. Food Sci., v. 70, n.2, pp.132-137, 2005.

[5] MESSION, J-L., SOK, N., ASSIFAOUI, A., et al., "Thermal Denaturation of Pea Globulins (Pisum sativum L.)-Molecular Interactions Leading to Heat-Induced Protein Aggregation”, J. Agric. Food Chem., v. 61, n.6, pp. 1196-1204, 2013.

[6] SUN, X.D, ARNTFIELD, S.D. "Gelation properties of salt-extracted pea protein induced by heat treatment”, Food Res. Int., v. 43, n.2, pp.509-515, 2010.

[7] LIANG H-N, TANG C-H. "pH-dependent emulsifying properties of pea [Pisum sativum (L.)] proteins", Food Hydrocoll., v. 33, n.2, pp. 309-319, 2013.

[8] DAGORN-SCAVINER, C, GUEGUEN, J, LEFEBVRE, J. "Emulsifying Properties of Pea Globulins as Related to Their Adsorption Behaviors", J. Food Sci., v.52, n.2, pp. 335-341, 1987.

[9] GHARSALlAOUI, A, ROUDAUT, G, CHAMBIN, O, et al., "Applications of spray-drying in microencapsulation of food ingredients: An overview”, Food Res. Int., v.40, n.9, pp.1107-1121, 2007.

[10] RUBIO, L.A, PÉREZ, A., RUIZ, R, et al., "Characterization of pea (Pisum sativum) seed protein fractions”, J. Sci. Food Agric., v. 94, n. 2, pp. 280-287, 2014.

[11] PEDROSA C, FERREIRA ST. "Deterministic pressure-induced dissociation of vicilin, the 7S storage globulin from pea seeds: effects of $\mathrm{pH}$ and cosolvents on oligomer stability", Biochemistry, v. 33, n.13, pp. 4046-4055, 1994.

[12] PEDROSA, C., FELICE, F.G., TRISCIUZZI, C., et al., "Selective neoglycosylation increases the structural stability of vicilin, the 7S storage globulin from pea seeds", Arch. Biochem. Biophys., v.382, n.2, pp.203-210, 2000.

[13] RANGEL, A., DOMONT, G.B., PEDROSA, C., et al., "Functional properties of purified vicilins from cowpea (Vigna unguiculata) and pea (Pisum sativum) and cowpea protein isolate", J. Agric. Food Chem., v.51, n.19, pp.5792-5797, 2003.

[14] BOYE JI, AKSAY S, ROUFIK S, et al., "Comparison of the functional properties of pea, chickpea and lentil protein concentrates processed using ultrafiltration and isoelectric precipitation techniques", Food Res. Int., v. 43, n.2, pp. 537-546, 2010.

[15] TANG C-H, SUN X, YIN S-W. "Physicochemical, functional and structural properties of vicilin-rich protein isolates from three Phaseolus legumes: Effect of heat treatment", Food Hydrocoll., v. 23, n.7, pp.1771-1778, 2009.

[16] WALTERS, R.H, BHATNAGAR, B., TCHESSALOV, S., et al., "Next generation drying technologies for pharmaceutical applications”, J. Pharm. Sci., v.103, n.9, pp. 2673-2695, 2014.

[17] RANGEL, A., SARAIVA, K., SCHWENGBER, P., et al., "Biological evaluation of a protein isolate from cowpea (Vigna unguiculata) seeds", Food Chem., v.87, n. 4, pp.491-499, 2004. 
[18] LOWRY, O.H, ROSEBROUGH, N.J, FARR, A.L, et al., "Protein measurement with the Folin phenol reagent”, J. Biol. Chem., v.193, n.1, pp.265-275, 1951.

[19] LAEMMLI, U.K. "Cleavage of structural proteins during the assembly of the head of bacteriophage T4”, Nature, v.227, pp.680-685, 1970.

[20] MENDES, A.N, FILGUEIRAS, L.A, PINTO, J.C, et al., "Physicochemical Properties of Rhamnolipid Biosurfactant from Pseudomonas aeruginosa PA1 to Applications in Microemulsions", J. Biomater. Nanobiotechnol., v. 6, n.1, pp.64-79, 2015.

[21] MENDES, A.N, HUBBER, I., SIQUEIRA, M, et al. "Preparation and Cytotoxicity of Poly(Methyl Methacrylate) Nanoparticles for Drug Encapsulation”, Macromol. Symp., v.319, n.1, pp. 34-40, 2012.

[22] PEREIRA, H.V.R., SARAIVA, K.P., CARVALHO, L.M.J., et al. "Legumes seeds protein isolates in the production of ascorbic acid microparticles", Food Res. Int., v. 42, n.1, pp.115-121, 2009.

[23] RUBIO, L.A, PÉREZ, A., RUIZ, R., et al., "Characterization of pea (Pisum sativum) seed protein fractions", J. Sci. Food Agric., v. 94, n.2, pp. 280-287, 2014.

[24] DZIUBA, J, SZERSZUNOWICZ, I, NALECZ, D, et al. "Proteomic analysis of albumin and globulin fractions of pea (Pisum sativum L.) seeds”, Acta Sci. Pol. Technol. Aliment., v.13, n.2, pp.181-190, 2014.

[25] DONSI, F., SENATORE, B., HUANG, Q., et al., "Development of novel pea protein-based nanoemulsions for delivery of nutraceuticals”, J. Agric. Food Chem., v.58, n.19, pp. 10653-10660, 2010.

[26] SINGH, A., VAN HAMME, J.D., WARD, O.P., "Surfactants in microbiology and biotechnology: Part 2", Application aspects. Biotechnol. Adv., v.25, n.1, pp. 99-121, 2007.

[27] BARAC, M., CABRILO, S., PESIC, M., et al., "Profile and functional properties of seed proteins from six pea (Pisum sativum) genotypes”, Int. J. Mol. Sci., v.11, n.12, pp.4973-4990, 2010.

[28] MORAES, S.L., REZENDE, M. "Determinação da concentração micelar crítica de ácidos húmicos por medidas de condutividade e espectroscopia”, Química, v.27, n.5, pp. 701-705, 2004.

[29] JIANG, J, ZHU, B, LIU, Y., et al., "Interfacial Structural Role of pH-Shifting Processed Pea Protein in the Oxidative Stability of Oil/Water Emulsions”, J. Agric. Food Chem., v.62, n.7, pp.1683-1691, 2014.

[30] OLIVEIRA, D.W.F., FRANCA, I.W.L., FELIX, A.K.N., et al. "Kinetic study of biosurfactant production by Bacillus subtilis LAMI005 grown in clarified cashew apple juice", Colloids Surf. B. Biointerfaces., v.101, pp.34-43, 2013. 